\title{
Urban Rooftop Area Assessment for Estimation of Rooftop Rainwater-Harvesting Potential
}

\author{
Mouli, T., Krupavathi, K. and Ganeswara Rao Ch. S.
}

Acharya N.G. Ranga Agricultural Unmiversity, Dr. NTR college of Agricultural Engineering, Bapatla, Guntur (Dt.), Andhra Pradesh State, Andhra Pradesh, India

*Corresponding author: tmouli4@gmail.com (ORCID ID: 0000-0003-4403-6729)

Paper No. 848

Received: 25-03-2020

Revised: $18-07-2020$

Accepted: 29-08-2020

\begin{abstract}
Rooftop water conservation is a promising technique for sustainable water resource management especially in urban areas. The tedious available roof top area estimation can be made easy with advances in geospatial technologies. The present study taken up to develop the roofing layer to estimate potential rooftop area from high resolution satellite imagery $(1 \mathrm{~m})$ i.e., Google earth Pro in GIS environment. The roof surfaces are considered as the micro catchments and GIS is employed to calculate the area of various types of roofs and their potential for planning of water harvest. The results are validated for errors in digitization by ground-truthing against 112 household systems through manual measurement. It is also attempted to identify the type of the roof to know the quality of the harvested water. The annual rainfall was analyzed to quantify the potential of the rainwater harvesting. The results of this study will demonstrate the Application capability of Google Earth Pro and GIS in estimating rainwater harvesting potential to tackle the prevailing water shortage. The estimated total roofing area is $818565.53 \mathrm{sq}$. $\mathrm{m}$. The results of the study revealed the huge potential of 71.154 cubic meter with $1 \mathrm{~mm}$ of uniform distribution of rainwater over the roof tops.
Highlights
( Remote sensing and GIS in estimation of Rooftop area
0 Manual validation with simple random sampling
(0 Roof top runoff potential estimation

Keywords: Rooftop, Rainwater, Harvesting Potential, GIS, geospatial environment

The availability of fresh water was the major challenge faced by the majority of the people for different non-potable and regular purposes like flushing, cleaning, gardening, laundry washing and cultivation etc. The lack of water from the water resources is called water scarcity is prevailing many the places of the world. Rainwater harvesting (RWH) is one of the best practices to overcome the scarcity of water (Hari et al. 2018). Rooftop rainwater harvesting among other options, plays a central role in addressing water security and reducing impacts on the environment. The small contribution from the rainwater harvesting technique was playing a major role in reducing the water scarcity.
Generally, harvesting rainwater is two types one is Surface runoff harvesting and the other is Rooftop rainwater harvesting (RTRWH). In rooftop rainwater harvesting, rainwater runoff is collected from various roof surfaces which typically offer dirt free water that can be used for drinking. To reduce groundwater contamination and to supplement groundwater supplies during lean seasons, to reduce runoff and to avoid flooding from roads rainwater harvesting is necessary.

How to cite this article: Mouli, T., Krupavathi, K. and Ganeswara Rao Ch. S. (2020). Urban Rooftop Area Assessment for Estimation of Rooftop Rainwater-Harvesting Potential. IJAEB, 13(3): 275-283.

Source of Support: None; Conflict of Interest: None (C) 9 
Harvested rainwater is a renewablesource of clean water that is ideal for domestic and landscape uses. Harvested Rainwater can be consumed for drinking and domestic purpose also (Baby et al. 2019). Harvested rainwater can be stored in a subsurface groundwater reservoir by replenishment of groundwater supply through artificial recharge techniques. Rainwater harvesting provides water at the point of demand, minimizes the stress on existing natural resources and also an eco-friendly solution. Capturing and storing rainwater for use is particularly important in dryland, hilly, urban and coastal areas. Rainwater harvesting in urban areas is a strategy that brings many benefits and may serve to cope with current water shortages, urban stream degradation, and flooding.

The history of rainwater harvesting in Asia can be traced back to about the $9^{\text {th }}$ or $10^{\text {th }}$ century and the small-scale collection of rainwater from roofs in the rural areas of South and South-east Asia. In India, Tamil Nadu is the first state which has made rooftop rainwater harvesting structure compulsory to all the houses across the state. Rainwater harvesting is also made compulsory in Pune (Maharashtra). In the state of Assam, rainwater harvesting is accomplished primarily through household rain catchment structures that are best suited for use in the villages in hilly areas, where people live in scattered huts or small settlements. The technology also has been adopted in the neighboring state of Meghalaya.

The assessment of the quantitative potential of rainwater harvesting and the quality of stormwater runoff from several types of roofs is essential to set up sustainable rainwater management. Planning Roof Water Harvesting is also cost-effective solution in case of big buildings with huge roof surface like offices and educational institutes and the amount of water which can be stored will give a promising solution to the water demand (Hari 2019). To estimate the potential of rainwater, the rooftop surface area and rainfall must be known. Estimation of rooftop area by manual means is tedious and time consuming. It will also lead to errors if there is no map of the area. Over the recent past, there has been a growing concern on the need for mapping and monitoring of crops, domestic and industries for decision-making over space and time (Krupavathi et al. 2018). Remote sensing and Geographical
Information System (GIS) have been widely used in urban environmental analysis (Norman et al. 2019). In assessment of rainwater harvesting potential using GIS, GIS is an effective tool for the estimation of surface area that can correlate spatially and retrieved for spatial analysis. With the application of GIS, it was possible to estimate the total amount of water harvestable at the household level (Shinde and Gaikwad 2016). The storm or annual storm runoff coefficient (RC/ASRC) plays a significant role in the quantification of the potential of rooftop catchments for rainwater harvesting.

Considering all these aspects, an attempt has been made to study the rainwater balance of the Bapatla town using remote sensing and GIS techniques. Another problem in Bapatla town is limited supply of municipal water. The conservation of rain water is very important to use for domestic purposes and to recharge ground water. Remote sensing and GIS technology is used to prepare thematic maps of other related features that directly influence rooftop rainwater harvesting. GIS was used to create more effective estimation of roof area.

\section{MATERIALS AND METHODS}

\section{Study area}

The present study was carried out in Bapatla town of Guntur district in Andhra Pradesh state. Bapatla is located in the southeastern part of the Guntur district of Andhra Pradesh is shown in Fig. 1. It is very close to the coast, the town experiences hot summers and cool winters. The maximum temperature ranges between $40{ }^{\circ} \mathrm{C}$ to $50{ }^{\circ} \mathrm{C}$ in summer and the minimum temperatures range between $18{ }^{\circ} \mathrm{C}$ to $25{ }^{\circ} \mathrm{C}$ in winter. The precipitation is very high and receives an annual rainfall of about $700-1150 \mathrm{~mm}$ with an average of $888.6 \mathrm{~mm}$. The study area (Bapatla) consists of 34 wards, ward wise municipality map of Bapatla were collected from the MRO office, Bapatla.

The municipal water is the only drinking water source in the study area supplied from the tank filled by Krishna waters. The water is supplied only for a limited time. There is a great demand for water in the town mainly for domestic purposes like drinking, washing, cleaning the building floors, for use in gardening purposes etc. Therefore; it is essential to adopt eco-friendly and renewable 

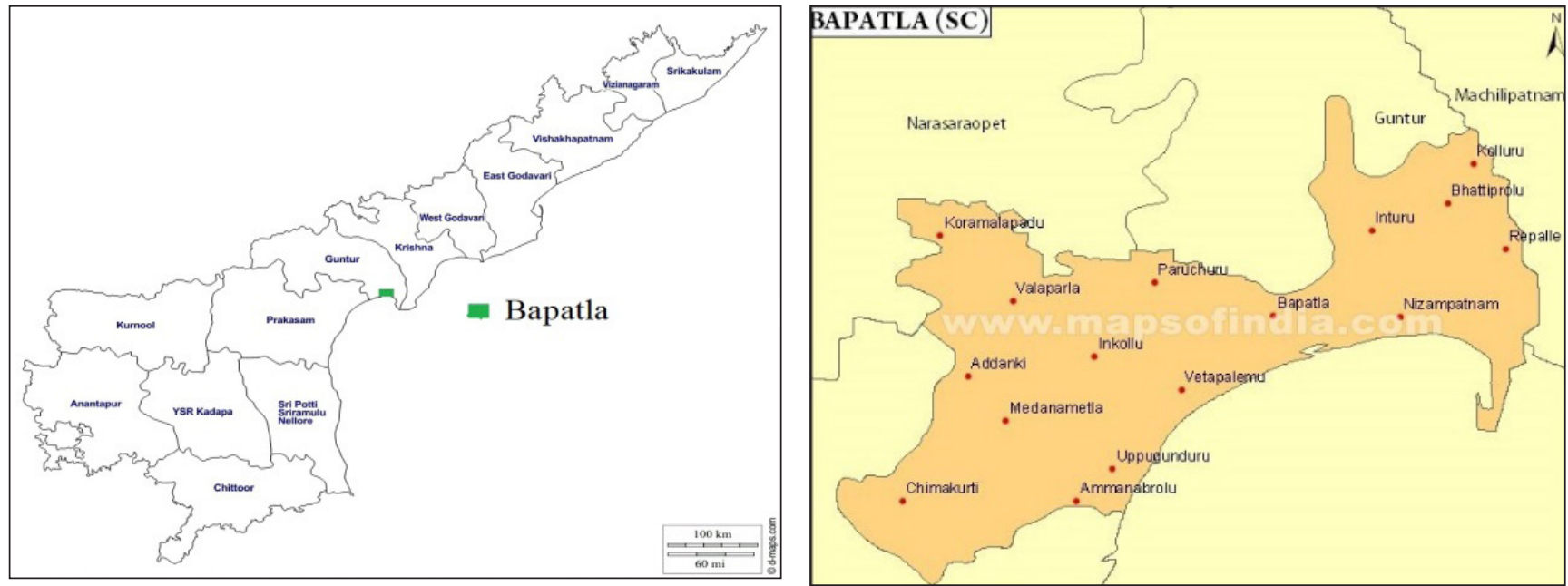

Fig. 1: Location of Bapatla in Andhra Pradesh state
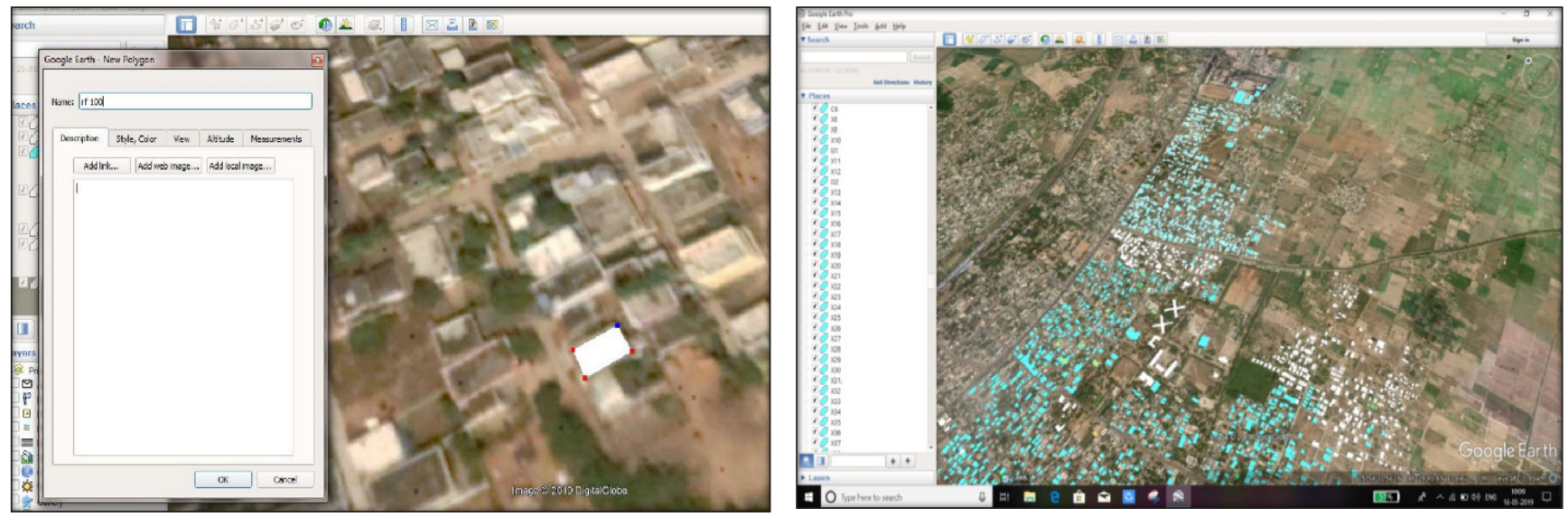

Fig. 2: View of drawing a polygon and a part of digitized rooftops in Bapatla town in Google Earth Pro

water conservation methods of rainwater. The harvested rainwater from rooftops can be stored in groundwater as shallow freshwater, which can be easily extracted for the above purposes. Hence the study was taken up to estimate the Rooftop Rainwater Harvesting Potential using Google Earth and GIS applications.

\section{Digitization and extraction of Roof top area}

Google Earth Pro was used to digitize the different types of roofs. Google Earth Pro is free and opensource software it offers premium high-resolution photos. Google earth pro displays satellite images of varying resolution of the earth's surface, allowing users to see things like cities and houses looking perpendicularly down or at an oblique angle, with perspective. Every type of rooftop of the study area was digitized using the polygon tool available in Google Earth Pro. The Digitized different types of rooftops in the Google Earth Pro were imported to QGIS and converted the digitized rooftops in . $\mathrm{kml}$ file to a shapefile and calculated the total roof area. QGIS (previously known as Quantum GIS) is a free and open-source desktop platform that supports viewing, editing, and analysis of geospatial data, to compute the area of various types of roofs in the study area each shapefile coordinate system is projected to WGS 84 coordinate system.

The steps involved in the calculation of the rooftop area are as follows:

(i) Drawing the Polygon of the required rooftop area using Google Earth Pro (Fig. 2)

(ii) Exporting Polygons from Google Earth Pro to QGIS (Fig. 3) 

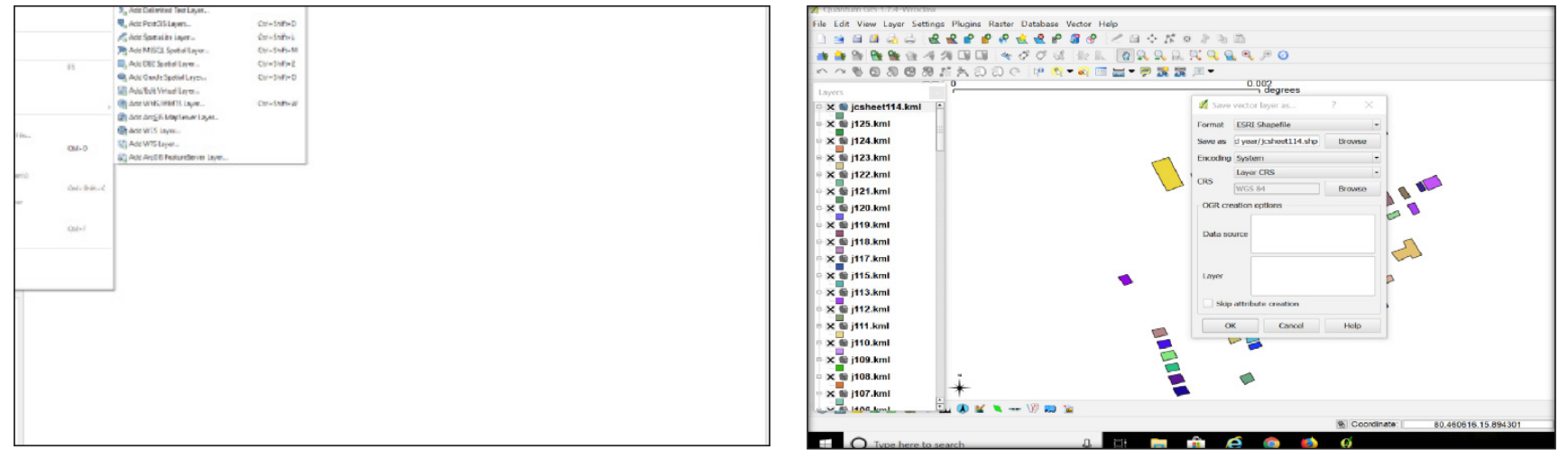

Fig. 3: Extraction of polygons and conversion of .kml file to shape file in QGIS
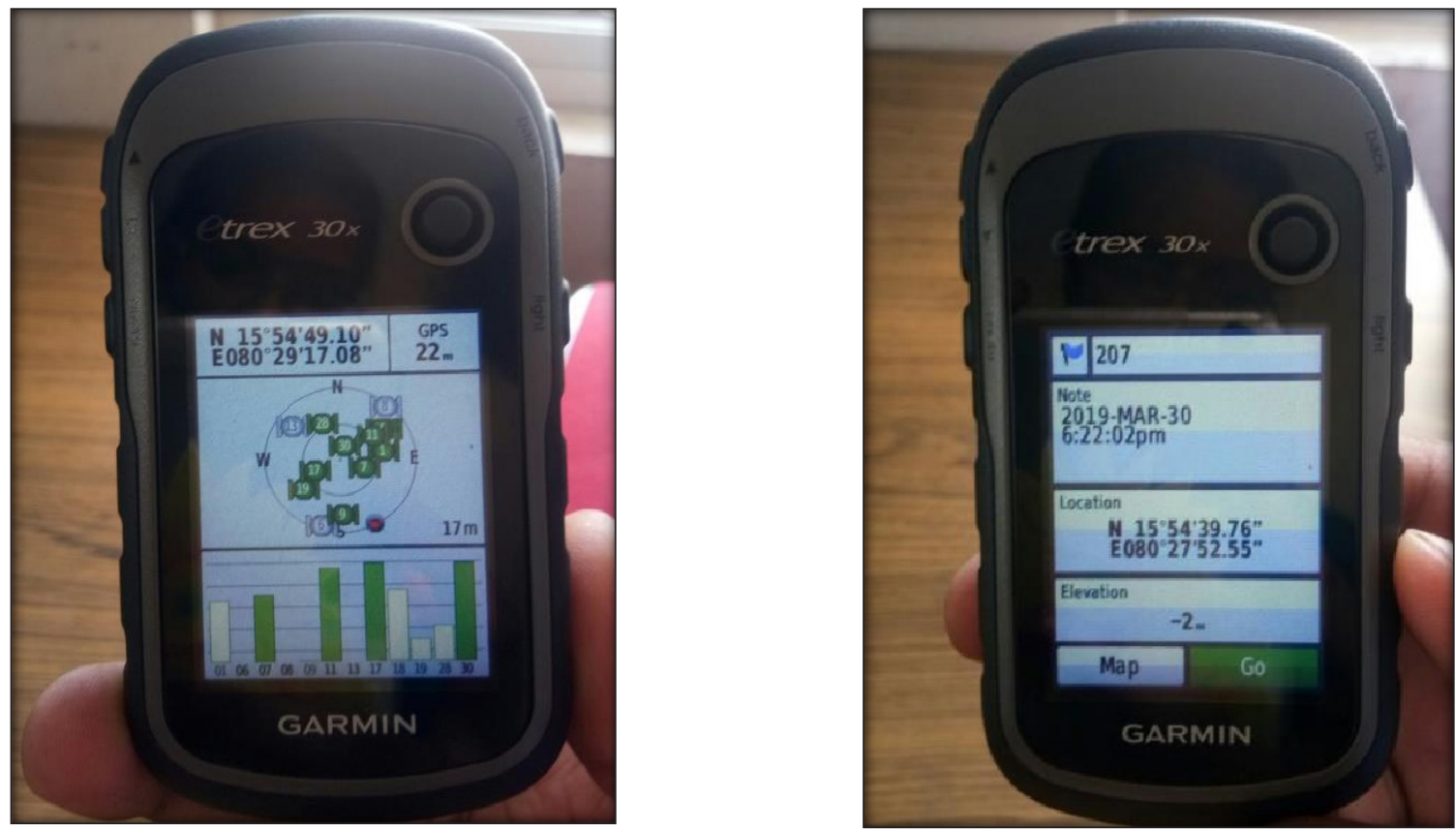

Fig. 4. Acquiring satellite signals in GPS device

(iii) Conversion of $\mathrm{kml}$ files to Shapefiles

(iv) Merging of all the shapefiles

(v) Addition of attributes to Attribute table

(vi) Calculation of area using various types of roofs using field calculator in QGIS

(vii) Estimation of Rainwater Harvesting Potential.

To verify the calculation of the rooftop area in this method, a ground truth survey was conducted using Garmin etrex-30x GPS to get location details in terms of unique geographic coordinates as shown in Fig. 4.

\section{Verification of digitized rooftop area with ground measured area}

Ground truth data are complementary to the remote sensing data as it helps to link the image data to the ground reality. It is governed by the amount of time that would be required for collecting data and also the accuracy of the output. Simple Random Sampling Pattern was used in this study. The observation sites are randomly chosen. Randomness ensures that all parts of the study area would have an equal chance of being sampled without any human bias. GPS was operated in a clear view of the sky and without obstructions nearby. The location and co-ordinates of the selected rooftops noted on the map. The exact location of the rooftop was found by using the GPS device with noted co-ordinates and the area of the particular rooftop was measured manually using $30 \mathrm{~m}$ tape. The co-ordinate pairs 
are then plotted on the image (Fig. 5). The area of rooftops obtained by using both the methods was verified by using the mean error in each ward of the Bapatla town.

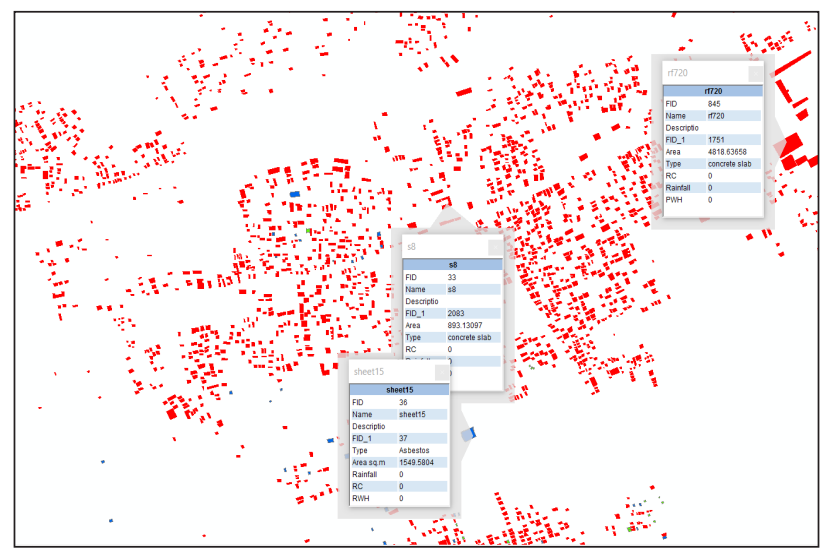

Fig. 5: Verification of details of digitized roofs

\section{Calculation of annual rainfall}

The rainfall data was collected from Chief Planning Officer, Guntur. The daily data of the rainfall for the years 2015, 2016, 2017 and 2018 was collected. The collected rainfall data was arranged day wise in each year and calculated monthly average rainfall for each month. The calculated monthly rainfalls were summed up to get annual rainfall of Bapatla town. The annual rainfall of all four years are calculated separately.

\section{Calculation of rooftop rainwater}

For assessment of collection of rainwater, it requires three parameters i.e. total rooftop area, average rainfall, runoff coefficient. The rooftop area calculated in previous sections was used for the calculation of rooftop rainwater. For each roof, the attributes of runoff coefficient, rainfall, runoff was added and respective entries were made. The Rooftop Rainwater Harvesting Potential is calculated by using the formula given below (Gould and Nissen 1999). Using the field calculator, the possible rainwater is harvested by using the following formula:

$$
R W H=P \times R_{C} \times A
$$

Where,

$R W H$ is the Rainwater harvested in cubic meter; $P$ is the annual rainfall in meter $(m) ; R_{C}$ is the Runoff coefficient, and The coefficient of rooftop $\left(R_{C}\right)$ for any catchment is defined as "The ratios between volumes of water that runs off to the total volume of rain that fall on the Rooftop". The Runoff coefficient of different structures given by Dadhich and Mathur (2016) is used in the present study is given in Table 1. For grass, the runoff coefficient is taken as 0 .

Table 1: Runoff coefficients for different types of roofs (Dadhich and Mathur, 2016)

\begin{tabular}{lll}
\hline S1. No. & Type of roof & Runoff coefficient \\
\hline 1 & Galvanized iron sheets & 0.9 \\
2 & Asbestos & 0.8 \\
3 & Cement concrete & 0.7 \\
4 & Grass & 0.0 \\
\hline
\end{tabular}

\section{RESULTS AND DISCUSSION}

\section{Roofing materials identified in Bapatla town}

The major rooftop materials identified in the Bapatla town are cement concrete, Galvanized iron sheets, Asbestos sheets, acrylic sheets and huts. Concrete is usually hard, made by mixing cement with sand, water and aggregate. Asbestos, acrylic and galvanized iron sheets are often used as corrugated roofing on sheds, garages and farms. A hut is a primitive dwelling, which may be constructed of various local materials with readily available materials such as wood, grass, palm leaves, branches, and mud using techniques passed down through the generations. It was observed while ground truthing, among the roofs, the collection of water from Asbestos, acrylic and galvanized iron sheet roofs is high, where there is possibility to get more than $90 \%$ of rainfall collection. The collection of rainwater from the huts is very difficult as roofs are in slanting position, water slides from all sides and also some water sinks into the roofs. Roof pitch is associated with building age and roofing material. These in turn are related to geographic regional variation in construction methods. Building direction (azimuth) is largely governed by road layout which is a reflection of local topography (Palmer et al. 2018).

\section{Digitized Rooftop area in the study area}

The digitized roof top area in Bapatla town is shown in Fig. 5. The total rooftop area covered in the Bapatla was found as $818565.53 \mathrm{Sq}$. $\mathrm{m}$. The major portion of area covered under cement concrete slab 
as 799586.34 Sq. $m$ followed by asbestos sheet, and hut were 18979.19, and 3652.48 Sq. m respectively (Table 2).

Table 2: Area covered under different roofs in Bapatla town

\begin{tabular}{ll}
\hline Roof type & Area covered (Sq. m) \\
\hline Cement concrete slab & 799586.34 \\
Asbestos sheets & 18979.19 \\
Huts & 3652.48 \\
\hline Total & $\mathbf{8 1 8 5 6 5 . 5 3}$ \\
\hline
\end{tabular}

Table 3 shows the locality wise rooftop area. The total area that is presented under Bapatla town is 818565.535 sq. $\mathrm{m}$. The highest roof area is found at the GBC Road Telephone Area of about 57520.376 sq. $\mathrm{m}$ followed by Railpet with roof area of 48226.033 Sq. $\mathrm{m}$. The lowest rooftop area was presented in Patel Nagar of about 15948 sq. m as the houses are widely spaced.

Table 3: Ward wise rooftop area digitized mean error of the actual and digitized area of rooftops in Bapatla

\begin{tabular}{|c|c|c|c|}
\hline \multicolumn{2}{|c|}{ S1. No. Locality } & \multirow{2}{*}{$\begin{array}{l}\begin{array}{l}\text { Digitized } \\
\text { area(m }\end{array} \text { ) } \\
19721.43\end{array}$} & \multirow{2}{*}{$\begin{array}{l}\text { Mean } \\
\text { Error \% } \\
0.62\end{array}$} \\
\hline 1 & Bethany colony & & \\
\hline 2 & Ramakrishnapuram & 46543.79 & 2.76 \\
\hline 3 & Railpet & 48226.03 & 0.50 \\
\hline 4 & Jamedarpet & 30321.62 & 1.46 \\
\hline 5 & Upparapalem & 44015.12 & 0.67 \\
\hline 6 & Mallikarjuna Bhrundavan & 45920.28 & 3.19 \\
\hline 7 & Chillaragollapalem & 19177.57 & 0.6 \\
\hline 8 & Viswabrahmana Colony & 32109.04 & 0.90 \\
\hline 9 & Srinivas Nagar Colony & 19990.75 & 1.03 \\
\hline 10 & Yadavpalem & 21473.46 & 0.52 \\
\hline 11 & Patel Nagar & 15948.05 & 1.63 \\
\hline 12 & Srungarapuram & 39531.50 & 0.99 \\
\hline 13 & Akbar Pet & 20103.19 & 0.23 \\
\hline 14 & Govt Hospital Area & 56413.49 & 0.42 \\
\hline 15 & Seelamvari Palem & 19902.49 & 0.58 \\
\hline 16 & Sanjay Gandhi Colony & 33669.22 & 0.21 \\
\hline 17 & Munnamvari Palem & 20666.61 & 0.41 \\
\hline 18 & Immadisettivari Palem & 23336.06 & 0.53 \\
\hline 19 & Vijayalakshmi Puram & 23058.70 & 0.91 \\
\hline 20 & Rangarao Thota & 25407.40 & 0.71 \\
\hline 21 & Bestapalem & 26217.90 & 1.04 \\
\hline 22 & Mpl Market Area & 34855.61 & 0.85 \\
\hline 23 & Islampet & 43611.11 & 1.20 \\
\hline 24 & Naralasettivari Palem & 25418.10 & 1.0 \\
\hline
\end{tabular}

\begin{tabular}{llll}
25 & Hyer Nagar, DM Palli & 25406.55 & 1.24 \\
26 & GBC Road Telephone & 57520.37 & 0.74 \\
& Excing Area & & \\
\hline Total & $\mathbf{8 1 8 5 6 5 . 5 3}$ & $\mathbf{0 . 3 2}$ \\
\hline
\end{tabular}

\section{Verification of digitized rooftop area with ground measured area}

The digitized rooftops in the Bapatla town were validated manually. Selection of roofs was done by using Simple random sampling technique for each ward in Bapatla town. The area wise mean error between actual and digitized values are shown in Table 3. The highest mean error was observed for the ward Mallikarjuna Brundavan is 3.19\%. The lowest mean error was at Sanjay Gandhi colony $0.21 \%$. The area measured by manual measurement is 15754.39 sq. $m$ and the same roof area measured using Google earth pro is 15703.27 sq. $\mathrm{m}$ and the difference between these two is $51.16 \mathrm{sq}$. $\mathrm{m}$. The total mean error is $0.32 \%$. The error in the above results is mainly due to parallax error and obstruction of trees, confusion of roofs etc.

\section{Annual rainfall in the town}

The main source of rainfall in Bapatla is South-West monsoon. The annual rainfall was 526.6, 781.1, 886.3 and $1050.1 \mathrm{~mm}$ for the years 2018, 2017, 2016 and 2015 respectively. The average annual rainfall during the study period is $844.483 \mathrm{~mm}$. The amount of rainfall was decreased from 2015 to 2018. It was observed that in all four years, there was no rainfall occurred during the months January to April.

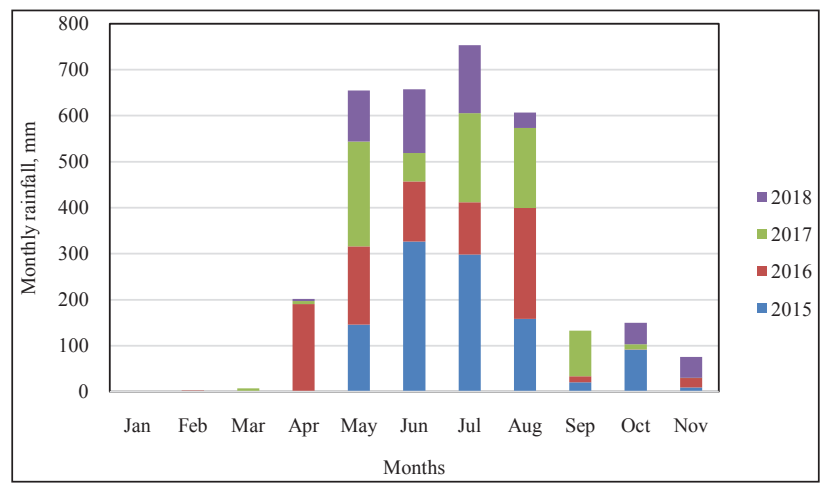

Fig. 6: Mean monthly rainfall of Bapatla town in different years

In some places, there were convective zones during May month and received small amount of rainfall. The receipt of rainfall was high during the months June to October. So, the rooftop rain water 


\begin{tabular}{|c|c|c|c|c|c|c|c|c|c|c|c|c|c|c|}
\hline & 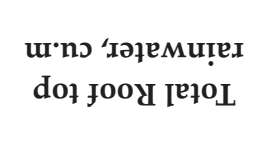 & 0 & & & 0 & $\begin{array}{l}\text { } \\
\stackrel{\vec{\rho}}{\hat{N}}\end{array}$ & $\begin{array}{l}\text { ते } \\
\infty \\
0 \\
0 \\
0 \\
0\end{array}$ & 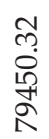 & 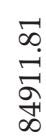 & 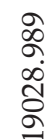 & 0 & & & \\
\hline$\stackrel{\infty}{=}$ & 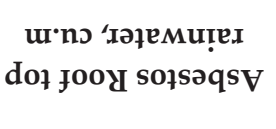 & 0 & 0 & 0 & 0 & 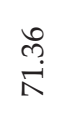 & $\begin{array}{l}\vec{m} \\
\text { i } \\
0 \\
0 \\
-1\end{array}$ & $\begin{array}{l}\text { के } \\
\infty \\
\infty \\
\text { ळे }\end{array}$ & 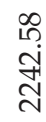 & 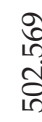 & 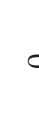 & & & \\
\hline & 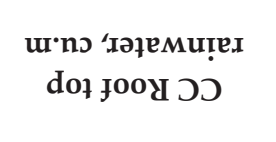 & 0 & 0 & 0 & 0 & $\begin{array}{l}\tilde{b} \\
\dot{0} \\
\tilde{ర} \\
\text { రి }\end{array}$ & 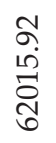 & 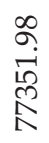 & 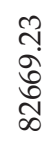 & $\begin{array}{l}\text { Iี } \\
\text { ถึं } \\
\infty\end{array}$ & $c$ & & & \\
\hline & 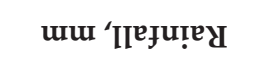 & 0 & 0 & 0 & 0 & $\stackrel{\curvearrowright}{+}$ & $\stackrel{\infty}{\circ}$ & $\begin{array}{l}\text { Na } \\
\infty \\
\infty \\
\infty\end{array}$ & 今 & $m$ & c & & & \\
\hline & 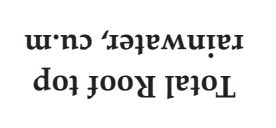 & 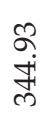 & 0 & $\circ$ & 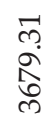 & 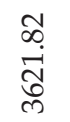 & 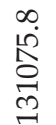 & 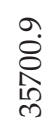 & $\begin{array}{l}\text { J゙ } \\
\text { İ } \\
\text { I }\end{array}$ & 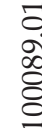 & 年 & & & \\
\hline & 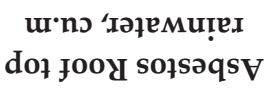 & $\vec{\sigma}$ & 0 & 0 & ન્̣ & $\begin{array}{l}\text { 茴 } \\
\text { బू. }\end{array}$ & 禹 & $\begin{array}{l}\infty \\
\infty \\
\stackrel{\mathcal{I}}{i}\end{array}$ & 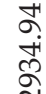 & f & 峦 & & & \\
\hline & 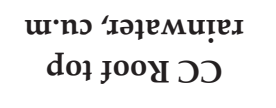 & $\begin{array}{l}1 \\
\infty \\
10 \\
\infty \\
\infty\end{array}$ & $\circ$ & $\circ$ & 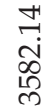 & 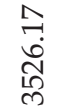 & 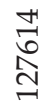 & $\begin{array}{l}\text { co } \\
\infty \\
10 \\
10 \\
\text { ff }\end{array}$ & $\frac{N}{\stackrel{2}{\infty}}$ & 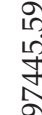 & $\begin{array}{l}c \\
1 \\
5 \\
15 \\
5\end{array}$ & & & \\
\hline & uu 'II'ju!̣ey & $\stackrel{0}{0}$ & $\circ$ & $\circ$ & ت艹 & 3̧ & $\stackrel{\sim}{\sim}$ & $\overrightarrow{\mathrm{J}}$ & ळ. & $\stackrel{5}{9}$ & 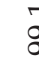 & & & \\
\hline & 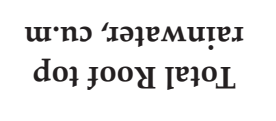 & $\begin{array}{l}\Omega \\
\text { f } \\
\text { m }\end{array}$ & $\begin{array}{l}\text { ले } \\
\text { Ni } \\
\infty\end{array}$ & 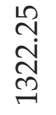 & $\begin{array}{l}\text { के } \\
\text { में }\end{array}$ & 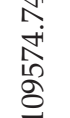 & $\begin{array}{l}\text { ô } \\
\text { o } \\
o \\
\text { مू }\end{array}$ & 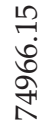 & 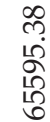 & $\begin{array}{l}\infty \\
j^{2} \\
9 \\
1 \\
1 \\
0 \\
c\end{array}$ & the & & & R \\
\hline 里 & $\begin{array}{c}\text { ur'no 'xәңемu!̣e. } \\
\text { doł jooy sołsaqsy }\end{array}$ & $\ddot{\sigma}$ & તิ & $\begin{array}{l}\text { ूे } \\
\text { ले }\end{array}$ & 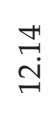 & $\begin{array}{l}\text { मे } \\
\text { ळूे } \\
\text { ஸे }\end{array}$ & 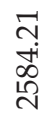 & $\begin{array}{l}\sigma \\
\text { مे } \\
\text { مે }\end{array}$ & స్ & 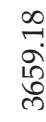 & s & & & है. \\
\hline & 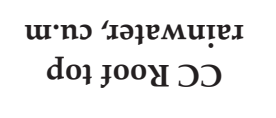 & $\begin{array}{l}\text { న } \\
10 \\
\infty \\
\infty\end{array}$ & 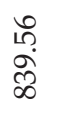 & 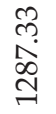 & 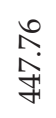 & $\begin{array}{l}\infty \\
0 \\
0 \\
0 \\
0 \\
0\end{array}$ & 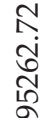 & 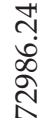 & $\begin{array}{l}\text { ठొ } \\
\text { iे } \\
\infty \\
0 \\
0\end{array}$ & $\begin{array}{l}\text { है } \\
\text { के } \\
\text { के } \\
\text { cे }\end{array}$ & 象 & & & $\overbrace{}^{\infty}$ \\
\hline & um 'IIeju!̣ey & $\stackrel{\circ}{\circ}$ & $\stackrel{n}{\stackrel{n}{r}}$ & $\stackrel{m}{i}$ & $\stackrel{\infty}{\circ}$ & \&் & 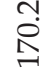 & $\stackrel{+}{\dot{m}}$ & 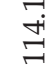 & 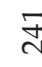 & 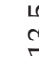 & & $\dot{\square}$ & 8 \\
\hline & 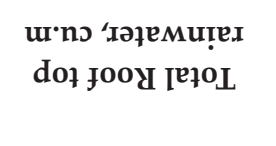 & 0 & 0 & 0 & 0 & 0 & $\begin{array}{l}\hat{N} \\
\infty \\
\infty \\
\infty\end{array}$ & 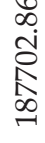 & $\stackrel{m}{\infty}$ & $\begin{array}{l}0 \\
\infty \\
\frac{1}{0} \\
\frac{1}{\sigma}\end{array}$ & 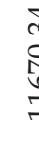 & & & है \\
\hline 12 & 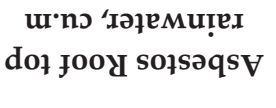 & 0 & 0 & 0 & 0 & 0 & 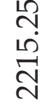 & 誉 & $\begin{array}{l}+ \\
\stackrel{+}{+} \\
\stackrel{+}{q}\end{array}$ & $\begin{array}{l}\infty \\
\stackrel{0}{0} \\
\stackrel{+}{+}\end{array}$ & ๙ૃ & & & \\
\hline & 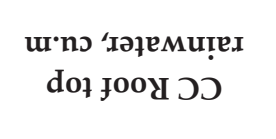 & 0 & 0 & 0 & 0 & 0 & 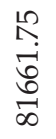 & 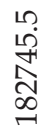 & 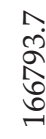 & $\begin{array}{l}\infty \\
0 \\
\stackrel{1}{\$} \\
\infty \\
\infty\end{array}$ & 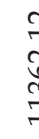 & & & \\
\hline & 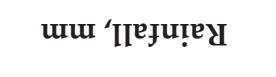 & 0 & 0 & 0 & 0 & 0 & ڤે & $\begin{array}{l}\text { Ln } \\
\text { तुं }\end{array}$ & $\stackrel{\infty}{~}$ & 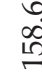 & ç & & & \\
\hline & 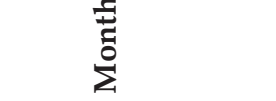 & ฮี & e्य & $\sum_{i}^{\pi}$ & $\frac{\vec{z}}{4}$ & $\stackrel{\vec{\pi}}{\Sigma}$ & $\Xi$ & $\exists$ & $\frac{b}{2}$ & ஸे & & & & \\
\hline
\end{tabular}


harvesting potential is high from June to October. In the year 2015, the highest rainfall was recorded in the month July followed by August and September i.e. 326.5, 298 and $158.6 \mathrm{~mm}$ respectively. In the year 2016, the highest rainfall was recorded in the month September followed by May and June i.e. 241, 190.6 and $170.2 \mathrm{~mm}$ respectively. In the year 2017, the highest rainfall was recorded in the month June followed by August and September i.e. 228, 193.3 and $174.1 \mathrm{~mm}$ respectively. In the year 2018, the highest rainfall was recorded in the month August followed by July and June i.e. 147.7, 138.2 and 110.8 $\mathrm{mm}$ respectively. The lowest rainfall is recorded in the month May as $4.7 \mathrm{~mm}$.

\section{Calculation of roof top rainwater}

Rain water that can be harvested from cement concrete slab and asbestos sheets. The quality of collected water is associated with building age and roofing material. These in turn are related to geographic regional variation in construction methods. The rainwater harvesting potential during different years is shown in Table 4 . In the year 2015 , the potential of harvesting rooftop rainwater is ranged from 5205.31 to 88770.08 cu.m in case of CC slab. Whereas 141.20 to $4957.36 \mathrm{cu} . \mathrm{m}$ in case of Asbestos. The highest amount of rooftop rain water potential from concrete slab and asbestos sheet is in the month of September, which is 88770.08 cu.m and 4957.36 cu.m respectively. In the year 2016, the potential of harvesting rooftop rainwater is ranged from 335.82 to 134890. 2 cu.m in case of CC slab. Whereas 9.11 to 3659.18 cu.m is observed in case of Asbestos. The highest amount of 365825.74 cu.m and $9923.841 \mathrm{cu} . \mathrm{m}$ rooftop rain water in the month of September from CC and asbestos respectively.

In the year 2017, the potential of harvesting rooftop rainwater is ranged from 55.97 to $108192.00 \mathrm{cu} . \mathrm{m}$ in case of CC slab. Whereas 1.51 to 2934.94 cu.m is observed in case of Asbestos. The potential of harvesting rooftop rainwater in the year 2018, is ranged from 2630.63to 365826.73 cu.m in case of CC slab. Whereas 261.15 to 9923.84 cu.m is observed in case of Asbestos. The highest amount of rooftop rainwater potential from concrete slab and asbestos sheet is in the month of October, which is 365825.74 cu.m and 9923.841 cu.m respectively. It was also observed that for the same area, the harvesting potential is high in case of Asbestos sheet compared to cement concrete. The results are in accordance with Dadhich and Mathur, 2016.

\section{Total Rooftop Rainwater Harvesting Potential}

The Rooftop rainwater harvesting potential with 1 $\mathrm{mm}$ precipitation was shown in Table 5. It was clear that for every $1 \mathrm{~mm}$ of rainfall in the study area, the rooftop rainwater harvesting potential from CC slab was $55.971 \mathrm{cu} . \mathrm{m}$. The same is $15.18 \mathrm{cu} . \mathrm{m}$ with asbestos sheets. The total rooftop rainwater harvesting potential is 71.154 cubic meter from both catchments. The 30 years mean annual rainfall in the study area is $1078.86 \mathrm{~mm}$ (Dash \& Kumar 2017). Therefore, the average annual rainwater harvesting potential was 620229.914 cubic meters. Apart from this, various elements that may affect the quality of rooftop harvested rainwater such as land use, roof type, rainfall variation, weather condition, and air quality (Radzali et al. 2018) must also consider while planning the roof top rainwater harvesting.

Table 5: The rooftop rainwater harvesting potential

\begin{tabular}{lllll}
\hline Roof type & $\begin{array}{l}\text { Area } \\
\text { covered } \\
\text { (Sq. } \mathbf{m})\end{array}$ & $\begin{array}{l}\text { Runoff } \\
\text { coefficients }\end{array}$ & $\begin{array}{l}\text { Rainfall } \mathbf{~} \mathbf{m} \\
\text { Harvesting } \\
\text { Potential in } \\
\text { cu. } \mathbf{~ m}\end{array}$ \\
\hline $\begin{array}{l}\text { Cement } \\
\text { concrete } \\
\text { slab }\end{array}$ & 799586.34 & 0.7 & 0.001 & 55.971 \\
$\begin{array}{l}\text { Asbestos } \\
\text { sheets }\end{array}$ & 18979.19 & 0.8 & 0.001 & 15.183 \\
$\begin{array}{l}\text { Huts } \\
\text { Total }\end{array}$ & $\mathbf{8 1 8 5 2 . 4 8}$ & 0.0 & 0.001 & 0.0 \\
\hline
\end{tabular}

\section{CONCLUSIONS}

The present study reveals the potential of rooftop rainwater harvesting to meet the general demands of water in the study area. Google Earth Pro was used for digitizing the available rooftops and QGIS was used to estimate the area of roofs and also to estimate the water harvesting potential. Final roofing layer was developed with integration results from Google earth Pro and ground truth. Thus, it can be inferred urban area of the Bapatla Mandal has a total of $818565.53 \mathrm{Sq}$. m. The highest roof area was found at the GBC Road Telephone area of about $57520.376 \mathrm{Sq}$. $\mathrm{m}$ followed by Railpet with roof area of $48226.033 \mathrm{Sq}$. m. The lowest rooftop area was presented in Patel Nagar of about 15948 
sq. $\mathrm{m}$. There was a huge potential of $71.154 \mathrm{cu} . \mathrm{m}$ with $1 \mathrm{~mm}$ of uniformly distributed rainfall. The highest annual roof top rain water harvesting potential was $603695.99 \mathrm{cu}$. $\mathrm{m}$ in the year 2015. Planning Roof Water Harvesting is a very costeffective and will give a promising solution to the water demand. However, the quality of rooftop harvested rainwater is affected by roofing materials, roofing conditions, roofing geometry, weather conditions, and surrounding land use conditions. Such information can then be compiled, mapped, and modeled in GIS to generate a spatial model.

\section{REFERENCES}

Baby, S.N., Arrowsmith, C. and Al-Ansari, N. 2019. Application of GIS for Mapping Rainwater-Harvesting Potential: Case Study Wollert, Victoria. Journal of Engineering, 11(1): 14-21.

Dadhich, G. and Mathur, P. 2016. A GIS-based Analysis for Rooftop Rainwater Harvesting. International Journal of Computer Science E Engineering Technology, 7(04): 129-143.

Dash, S.S. and Kumar, H.H. 2017. Statistical and Trend Analysis of Climate Data of Bapatla (AP), India. Int. J. Curr. Microbiol. Appl. Sci., 6: 4959-4969.

Gould, J. and Nissen-Petersen, E. 1999. Rainwater catchment systems for domestic supply. Intermediate Technology. https://doi.org/10.3362/9781780445694.000

Hari, D. 2019. Estimation of Rooftop Rainwater Harvesting Potential using Applications of Google Earth Pro and GIS. International Journal of Innovative Technology and Exploring Engineering, 8(9): 2278-3075.
Hari, D., Reddy, K.R., Vikas, K., Srinivas, N. and Vikas, G. 2018. Assessment of rainwater harvesting potential using GIS. Journal of In IOP Conference Series: Materials Science and Engineering, 330(1): 012119.

Krupavathi, K., Raghu Babu, M., Mani, A., Parasad, P.R.K. and Edukondalu, L. 2018. Use of Landsat-8 OLI Imagery Multi-Temporal Vegetation Indices for Crop Classification in the Irrigated Areas of Krishna Central Delta. The Andhra Agric. J., 65(spl): 313-319.

Norman, M., Helmi, Z.M., Shafri, Shattri, B. and Yusuf, M.B. 2019. Review of remote sensing and geospatial technologies in estimating rooftop rainwater harvesting (RRWH) quality. International Soil and Water Conservation Research, 7(3): 266-274.

Palmer, D., Elena Koumpli, Ian Cole, Ralph Gottschalg and Thomas Betts. 2018. S-Based Method for Identification of Wide Area Rooftop Suitability for Minimum Size PV Systems Using LiDAR Data and Photogrammetry. Energies, 11: 3506.

Radzali, N.A. W.M., H.Z.M. Shafri, M. Norman, S. Saufi. 2018. Roofing assessment for rooftop rainwater harvesting adoption using Remote Sensing and GIS approach. The International Archives of the Photogrammetry, Remote Sensing and Spatial Information Sciences, XLII-4/W9: 129-131.

Shinde, S.D. and Gaikwad, V. 2016. Application of GIS for mapping rainwater harvesting potential: a case study of Nidhal village in Satara district, Maharashtra, India: https://doi.org/10.18311/ajprhc/2017/15793 
